\title{
Retraction Note: Temporal activation of anti- and pro-apoptotic factors in human gingival fibroblasts infected with the periodontal pathogen, Porphyromonas gingivalis: potential role of bacterial proteases in host signalling
}

Sonya Urnowey ${ }^{1}$, Toshihiro Ansai ${ }^{2}$, Vira Bitko ${ }^{1}$, Koji Nakayama ${ }^{3}$, Tadamichi Takehara ${ }^{2}$ and Sailen Barik ${ }^{1 *}$

Retraction note: BMC Microbiol 2006, 6 https://doi.org/10.1186/1471-2180-6-26

The Editor has retracted this article [1] following an investigation by the University of South Alabama which found:

- The same Western blot images were used for Caspase-7 (Fig. 4C) and AKT (Ser473, MT + I) (Fig. 7)

- In Fig. 4D, the $6 \mathrm{~h}$ band for MT was replicated, the image was then inverted and the band was used for the $36 \mathrm{~h}$ time point

- In Fig. 7, the same Western blot image was used to demonstrate responses in MT + I for PDK-1 (P-Ser241) and P-GSK-3beta

- In Fig. 7, the blot for P-FKHR-L1 at time point 0 was replicated and used for the $24 \mathrm{~h}$ time point

Sailen Barik, Vira Bitko, Toshihiro Ansai and Sonya Urnowey do not agree with this retraction. Koji Nakayama and Tadamichi Takehara have not responded to any correspondence about this retraction.

\section{Author details}

'Department of Biochemistry and Molecular Biology, University of South Alabama, College of Medicine, 307 University Blvd., Mobile, AL 36688-0002, USA. ${ }^{2}$ Department of Preventive Dentistry, Kyushu Dental College, Kitakyushu 803-8580, Japan. ${ }^{3}$ Division of Microbiology and Oral Infection, Nagasaki University Graduate School of Biomedical Sciences, Sakamoto 1-7-1, Nagasaki 852-8588, Japan.
Published online: 17 October 2019

Reference

1. Urnowey S, Ansai T, Bitko V, Nakayama K, Takehara T, Barik S. Temporal activation of anti- and pro-apoptotic factors in human gingival fibroblasts infected with the periodontal pathogen, Porphyromonas gingivalis: potential role of bacterial proteases in host signalling. BMC Microbiol. 2006; 6:26. https://doi.org/10.1186/1471-2180-6-26.

* Correspondence: sbarik@jaguar1.usouthal.edu
${ }^{1}$ Department of Biochemistry and Molecular Biology, University of South Alabama, College of Medicine, 307 University Blvd., Mobile, AL 36688-0002, USA

Full list of author information is available at the end of the article

(C) The Author(s). 2019 Open Access This article is distributed under the terms of the Creative Commons Attribution 4.0 International License (http://creativecommons.org/licenses/by/4.0/), which permits unrestricted use, distribution, and reproduction in any medium, provided you give appropriate credit to the original author(s) and the source, provide a link to the Creative Commons license, and indicate if changes were made. The Creative Commons Public Domain Dedication waiver (http://creativecommons.org/publicdomain/zero/1.0/) applies to the data made available in this article, unless otherwise stated. 